\title{
Glycerol as source of energy in broiler chicken fattening
}

\author{
Leo Kroupa, Pavel Suchý, Eva Straková, Ivan Herzig \\ Department of Nutrition, Animal Husbandry, and Animal Hygiene, Faculty of Veterinary Hygiene and Ecology, \\ University of Veterinary and Pharmaceutical Sciences Brno, Czech Republic
}

Received April 29, 2010

Accepted September 21, 2010

\begin{abstract}
The objective of this study was to verify the possibility of replacing soybean oil in a diet with glycerol, and investigate the effect of glycerol on performance indicators and health in broiler chickens. The experiment was performed on 122 one-day-old chickens that were divided based on sex into two control groups (30 females and 31 males) and two experimental groups (30 females and 31 males). Half $(50 \%)$ of the soybean oil in diets used in the experimental groups was replaced with glycerol at a ratio of 1:2. On 15, 32 and 38 day of age chickens of both sexes in the experimental group that were fed with diets containing glycerol showed significantly higher $(p \leq$ 0.01 ) mean body weight compared to the control group. At the end of the experiment, the mean weight of chickens in the control group was $2.078 \mathrm{~kg}$, whereas the mean weight of chickens in the experimental group was $2.341 \mathrm{~kg}$. In females, the overall consumption of diets within 38 days of fattening was $3.588 \mathrm{~kg}$ in the control group and $4.011 \mathrm{~kg}$ in the experimental group, in males, it was $3.915 \mathrm{~kg}$ in the control group and $4.366 \mathrm{~kg}$ in the experimental group, i.e. it was higher in experimental chickens. Feed conversion in chickens in experimental groups was better, being $1.84 \mathrm{~kg}$ in the control group and $1.81 \mathrm{~kg}$ in the experimental group in females, and $1.73 \mathrm{~kg}$ in the control group and $1.72 \mathrm{~kg}$ in the experimental group in males. It follows from our results that the optimum amount of glycerol in feed for poultry is $5 \%$. This study presents an original solution to optimize feed formula by replacing plant oil with glycerol. The results of the study can improve production indicators and economy in broiler fattening.
\end{abstract}

Rapeseed methylester, amino acids, fatty acids, gross energy, performance indicators

The gradually increasing biodiesel production (rapeseed oil methylester) poses a problem of the utilization of glycerol as a by-product of this technology. Since the amount of glycerol generated during the production of methylester exceeds the demands of industry (e.g., chemical industry), new alternatives for its use are currently being sought. Animal production seems to be a promising field to use glycerol as a source of energy in relatively large amounts, ensuring the optimum way of its recycling at the same time.

The use of glycerol in the nutrition of farm animals was first mentioned in the 1960s and 1970s. For example, some of the studies investigated the effect of dietary glycerol on reproduction of sows and on the composition of fatty acids in lipids in fat tissue (Neville et al. 1970; Demarne et al. 1977), or reported the use of glycerol in poultry nutrition and its effect on reproduction (Neville et al. 1971; Westfall and Howarth 1976). The use of glycerol in feeds for chickens was reported by Renner and Elcombe (1964), and by Carew and Foss (1974). Emmanuel et al. (1983) studied the effect of glycerol on the synthesis of glucose in fattened chickens whereas Lin et al. (1976) investigated the effect of glycerol on the activity of lipogenic enzymes and the synthesis of fatty acids.

According to most authors, the optimum content of glycerol in diets for broiler chickens is in the range of 5-10\% (Simon et al. 1996; Barteczko and Kaminski 1999; Cerrate et al. 2006). When included at this amount, crude glycerol showed a positive effect on performance characteristics, with no negative effect being observed on feed conversion. The dose of $25 \%$ of glycerol was associated with pathological changes in organs and had a negative effect on performance indicators in broiler chickens (Simon et al. 1997). Dozier

Address for correspondence:

MVDr. Leo Kroupa

Department of Nutrition, Animal Husbandry, and Animal Hygiene

Faculty of Veterinary Hygiene and Ecology

University of Veterinary and Pharmaceutical Sciences Brno

Palackého 1/3, 61242 Brno, Czech Republic

Phone: +420541562 671

Fax: +420541562675

E-mail: leo.kroupa@centrum.cz

http://www.vfu.cz/acta-vet/actavet.htm 
et al. (2008) supplemented the diet for broiler chickens with 3, 6 and 9\% of glycerol in individual phases of the fattening period, and monitored not only performance indicators (feed intake, body weight) but also the intake and excretion of energy and nitrogen. Their results showed that the apparent metabolizable energy (ME) of glycerol was effectively utilized by broiler chickens and that glycerol could be used as a source of energy in the diets for broiler chickens. However, what still has to be specified is the acceptable content of residual methanol that originates from the separation of fatty acids in biodiesel production (Cerrate et al. 2006). One positive finding is that glycerol improves technological and hygienic quality of granules, as reported by Schröder and Südekum (1999). Glycerol doses above $100 \mathrm{~g}$ per $\mathrm{kg}$ of feed may cause technological problems in the granulation of diets.

The aim of this study was to verify the possibility of replacing $50 \%$ of soybean oil with glycerol in a diet at a ratio of $1: 2$, and to examine the effect of glycerol on performance indicators and health in broiler chickens.

\section{Materials and Methods}

The comparative feeding trial was performed on meat type ROSS 308 hybrid of broiler chickens in the accredited experimental enclosure of the Department of Nutrition, Animal Husbandry and Animal Hygiene, Faculty of Veterinary Hygiene and Ecology, University of Veterinary and Pharmaceutical Sciences, Brno. The experiment was conducted on 122 one-day-old chickens that were divided (according to sex) to two control groups $\mathrm{C} 1$ and $\mathrm{C} 2$ (30 females and 31 males) and two experimental groups G1 and G2 (30 females and 31 males). Chickens were kept and fed in compliance with the technological procedure for ROSS 308 combination hybrid chickens, on deep bedding, at a density of 1 chicken per $0.25 \mathrm{~m}^{2}$. Chickens were fed three kinds of diets in form of mash during the experiment: pre-fattening diet (BR 1) from 1-14 days of age, fattening diet from 15-31 days of age (BR 2), and post-fattening diet from 31 to 38 days of age (BR 3). The feed was administered in self-feeders; water was provided from hat-shaped waterers, both were available ad libitum.

Diets were analysed prior to the feeding trial. Dry matter was determined gravimetrically by drying the sample at required conditions $\left(105^{\circ} \mathrm{C}\right)$. The content of nitrogen was determined by the Kjeldahl method using the Buchi analyser (Centec automatika, spol. s.r.o.). The content of crude protein in the feed was determined by multiplying the result by a coefficient of 6.25 . The content of crude fat was determined by extraction using $\mathrm{ANKOM}^{\mathrm{XT} 10}$ Fat Analyser (O.K. Servis BioPro, Czech Republic). Crude fibre was determined using ANKOM ${ }^{220}$ Fiber Analyser (O.K. Servis BioPro). Ash content was determined gravimetrically after the burning of a sample at a temperature of $550{ }^{\circ} \mathrm{C}$ at defined conditions. Calcium, phosphorus, and magnesium were determined by combustion and extraction followed by titration. The content of nitrogen free extractives (NFE) was calculated.

The amino acid spectrum was determined after acid hydrolysis of the feed sample with $6 \mathrm{~N} \mathrm{HCl}$, at $110{ }^{\circ} \mathrm{C}$ for a period of $24 \mathrm{~h}$, using AAA 400 (INGOS a.s. Praha, Czech Republic) automatic amino acid analyser on the basis of colour reaction between amino acids and an oxidation reagent (ninhydrin). In order to evaluate the quality of fat, gas chromatography was carried out to determine the contents of individual fatty acids using a GC 2010 Shimadzu Gas Chromatograph (Shimadzu, Japan). The extraction of fat from meat for determining the composition of fatty acids, especially PUFAs, was performed according to Hara and Radin (1978). The determination of heat of combustion (MJ.kg-1) was determined by calorimetry, combusting the feed sample in a bomb calorimeter in oxygen atmosphere, using AC 500 (Leco, USA).

Diets were prepared from the basic diet according to the procedure described below, in the Institute's feed mixing facility. In diets intended for experimental groups of chickens, $50 \%$ soybean oil was replaced with glycerol at a ratio of 1:2; one portion of soybean oil was replaced with two portions of glycerol. Pure glycerol (E 422 ) contains $98 \%$ of glycerol in dry matter. It is an additive as defined in Regulation No. 318/2003 (Anonymous 2003). Pure glycerol used in the experiment provided $15.3 \mathrm{MJ} \cdot \mathrm{kg}^{-1} \mathrm{GE}$.

Control and experimental diets $(50 \mathrm{~kg})$ were prepared from the basic diet. The control diet for pre-fattening (BR1) was prepared using $48.50 \mathrm{~kg}$ basic diet and $1.5 \mathrm{~kg}$ soybean oil, the experimental diet for pre-fattening included $47.75 \mathrm{~kg}$ basic diet, $0.75 \mathrm{~kg}$ soybean oil and $1.5 \mathrm{~kg}$ glycerol. The control diet for fattening (BR2) was prepared from $48.20 \mathrm{~kg}$ basic diet and $1.8 \mathrm{~kg}$ soybean oil, whereas the experimental diet for fattening included $47.30 \mathrm{~kg}$ basic diet, $0.9 \mathrm{~kg}$ soybean oil and $1.8 \mathrm{~kg}$ glycerol. The control diet for post-fattening (BR3) was prepared from $47.80 \mathrm{~kg}$ basic diet and $2.2 \mathrm{~kg}$ soybean oil, the experimental diet for post-fattening was prepared from $46.70 \mathrm{~kg}$ basic diet, $1.1 \mathrm{~kg}$ soybean oil and $2.2 \mathrm{~kg}$ glycerol.

In the course of the experiment, the growth intensity in broiler chickens was monitored by weighing individual chickens at 1, 15, 32 and 38 days of age. Mean daily weight gain was calculated for the individual phases of fattening and for the whole period of fattening. The consumption of diet was monitored daily and feed conversion was calculated. Throughout the whole period of fattening, the health condition of chickens was examined and the mortality rate was recorded. 
Results were processed using mathematical and statistical methods implemented in UNISTAT for Excel, version 56, and using the Tukey-HSD multiple comparison test. Differences between the mean values were tested at the level of significance being $p \leq 0.01$ and $p \leq 0.05$.

\section{Results}

The substitution of soybean oil with glycerol resulted in changes in the contents of nutrients in diets (Table 1). In experimental diets $(\mathrm{G})$, the content of NNES and $\mathrm{NaCl}$ increased whereas the content of total protein decreased, particularly in the diet BR 2 and BR 3; the content of crude fat and starch also decreased. The replacement of soybean oil with glycerol (the $\mathrm{G}$ group) resulted in a slight decrease in the contents of most amino acids (AA) which corresponded with the finding of a lower content of total protein in experimental diets. The BR 1 diet showed minimum differences in the amino acid spectrum, which is most likely attributed to a common and permissible analytical error. When the content of glycerol in diets was higher, the differences increased.

Table 1. Changes in the contents of nutrients in diets for chickens after the replacement of soybean oil by glycerol $\left(\mathrm{g} \cdot \mathrm{kg}^{-1}\right.$ in $100 \%$ dry matter)

\begin{tabular}{lcccccc}
\hline & \multicolumn{2}{c}{ BR1 } & \multicolumn{2}{c}{ BR2 } & \multicolumn{2}{c}{ BR3 } \\
& Control & Experiment & Control & Experiment & Control & Experiment \\
\hline $\mathrm{Ca}$ & 11.18 & 11.39 & 9.95 & 9.96 & 9.95 & 9.96 \\
$\mathrm{P}$ & 8.61 & 8.77 & 7.72 & 7.44 & 7.72 & 7.44 \\
$\mathrm{Mg}$ & 2.72 & 2.72 & 2.74 & 2.75 & 2.74 & 2.75 \\
$\mathrm{NaCl}$ & 2.6 & 5.9 & 2.9 & 6.0 & 2.9 & 6.0 \\
$\mathrm{CP}$ & 258.4 & 257.4 & 245.9 & 240.3 & 245.9 & 240.3 \\
Crude fat & 51.6 & 36.5 & 58.0 & 39.0 & 58.0 & 39.0 \\
Crude fibre & 24.3 & 24.1 & 26.3 & 27.5 & 26.3 & 27.5 \\
NFE & 599.9 & 613.5 & 609.9 & 633.2 & 609.9 & 633.2 \\
Starch & 411.7 & 394.6 & 415.0 & 400.6 & 415.0 & 400.6 \\
Ash & 65.8 & 68.4 & 59.8 & 59.9 & 59.8 & 59.9 \\
ME (MJ $\left.\cdot \mathrm{kg}^{-1}\right)$ & 12.9 & 12.4 & 13.3 & 12.3 & 13.3 & 12.3 \\
GE (MJ $\left.\cdot \mathrm{kg}^{-1}\right)$ & 18.99 & 18.6 & 19.1 & 18.7 & 19.1 & 18.7 \\
\hline
\end{tabular}

BR1 - diet for pre-fattening, BR2 - diet for fattening, BR3 - diet for post-fattening, $\mathrm{CP}$ - crude protein, $\mathrm{NFE}$ - nitrogen-free extractives, ME - metabolisable energy, GE - gross energy

The replacement of soybean oil with glycerol resulted in qualitative changes in the contents of fatty acids (FAs) between control and experimental diets, as documented in Table 3. In the BR 1 experimental diet, the total content of FAs decreased to $67.78 \%$ (i.e. by $32.22 \%$ ) compared to the BR 1 control diet. This decrease in the total content of FAs was associated with a decrease in individual FAs ranging from 16.98\% (lauric acid, C12:0) to $43.55 \%$ (caprylic acid, C 8:0). In the BR 2 experimental diet, the total content of FAs decreased to $66.22 \%$ (i.e. by $33.78 \%$ ) compared to the BR 2 control diet. The overall decrease in the total content of FAs was associated with a decrease in individual FAs from $18.50 \%$ (lauric acid, C12:0) to $39.06 \%$ (erucic acid, C22:1n9). In the BR 3 diet, the total content of FAs dropped by $39.85 \%$ compared to the BR 3 control diet. Reduction in the total content of FAs was also associated with a decrease in the contents of individual FAs, ranging from $4.57 \%$ (caproic acid, C6:0) to $45.02 \%$ (myristic acid, C14:0).

The development of body weight in chickens (according to sex, throughout the experiment) is given in Table 4. On days 15,32 and 38 of fattening, the mean body weight in chickens that were fed diets containing glycerol was significantly higher compared to the control group. Differences between group $\mathrm{C}$ and group $\mathrm{G}$ in the body weight of chickens on 
Table 2. Changes in the qualitative composition of amino acids in diets for chickens after the replacement of soybean oil with glycerol (100\% dry matter)

\begin{tabular}{lrrrrrr}
\hline & \multicolumn{2}{c}{ BR1 } & \multicolumn{2}{c}{ BR2 } & \multicolumn{2}{c}{ BR3 } \\
Amino acid & Control & Experiment & Control & Experiment & Control & Experiment \\
\hline Aspartic acid & 23.36 & 23.41 & 20.89 & 20.47 & 19.00 & 17.71 \\
Threonin & 10.17 & 9.41 & 8.13 & 8.26 & 8.14 & 7.15 \\
Serin & 11.85 & 11.09 & 10.16 & 10.07 & 9.73 & 9.31 \\
Glutamic acid & 46.27 & 45.70 & 43.69 & 43.43 & 42.18 & 38.71 \\
Proline & 12.12 & 11.90 & 11.81 & 11.81 & 13.68 & 12.83 \\
Glycine & 9.95 & 9.75 & 9.03 & 8.93 & 8.93 & 7.95 \\
Alanine & 9.50 & 9.41 & 8.47 & 8.48 & 8.37 & 7.61 \\
Valine & 12.52 & 12.43 & 11.40 & 11.20 & 10.06 & 9.42 \\
Methionine & 5.81 & 6.27 & 4.97 & 4.86 & 4.30 & 3.75 \\
Isoleucine & 9.83 & 9.63 & 8.92 & 8.82 & 8.48 & 7.95 \\
Leucine & 20.34 & 20.39 & 18.52 & 18.66 & 16.62 & 15.21 \\
Tyrosine & 7.38 & 8.18 & 7.00 & 7.46 & 6.45 & 6.02 \\
Phenylalanine & 11.73 & 11.76 & 10.39 & 10.63 & 10.29 & 8.97 \\
Histidine & 7.49 & 7.51 & 6.55 & 6.90 & 5.54 & 5.68 \\
Lysine & 15.98 & 16.02 & 13.44 & 13.23 & 11.20 & 11.47 \\
Arginine & 18.44 & 18.37 & 16.48 & 16.29 & 15.15 & 14.98 \\
Total & 232.74 & 231.23 & 209.85 & 209.50 & 198.12 & 184.72 \\
\hline BR1 & & & & &
\end{tabular}

BR1 - diet for pre-fattening, BR2 - diet for fattening, BR3 - diet for post-fattening

Table 3. Changes in the contents of fatty acids in diets for chickens after the replacement of soybean oil with glycerol

\begin{tabular}{lrrrrrr}
\hline & \multicolumn{2}{c}{ BR1 } & \multicolumn{2}{c}{ BR2 } & \multicolumn{2}{c}{ BR3 } \\
Fatty acids & Control & Experiment & Control & Experiment & Control & Experiment \\
\hline Capronic acid (C6:0) & 0.002 & 0.002 & 0.002 & 0.001 & 0.002 & 0.002 \\
Caprylic acid (C8:0) & 0.002 & 0.001 & 0.002 & 0.001 & 0.001 & 0.001 \\
Lauric acid (C12:0) & 0.008 & 0.007 & 0.007 & 0.006 & 0.005 & 0.003 \\
Tridecanoic acid (C13:0) & - & - & - & - & 0.0006 & 0.0004 \\
Myristic acid (C14:0) & 0.040 & 0.026 & 0.049 & 0.037 & 0.049 & 0.027 \\
Palmitic acid (C16:0) & 4.901 & 3.440 & 5.299 & 3.717 & 5.797 & 3.736 \\
Palmitoleic acid (C16:1) & 0.053 & 0.040 & 0.065 & 0.049 & 0.068 & 0.039 \\
Heptadecanoic acid (C17:0) & 0.044 & 0.028 & 0.046 & 0.031 & 0.053 & 0.033 \\
Stearic acid (C18:0) & 1.356 & 0.900 & 1.523 & 0.930 & 1.723 & 0.967 \\
Oleic acid (C18:1n9t) & 12.744 & 8.416 & 14.663 & 9.167 & 15.833 & 9.078 \\
Linoleic acid (C18:2n6c) & 19.615 & 13.479 & 21.291 & 14.567 & 23.265 & 14.327 \\
$\gamma$-linolenic acid (C18:3n6) & 2.277 & 1.464 & 2.486 & 1.592 & 2.607 & 1.490 \\
Arachidic acid (C20:4n6) & 0.182 & 0.126 & 0.211 & 0.129 & 0.198 & 0.121 \\
cis-11-eicosenoic acid (C20:3n3) & 0.179 & 0.121 & 0.207 & 0.141 & 0.201 & 0.117 \\
Behemic acid (C22:0) & 0.168 & 0.132 & 0.213 & 0.137 & 0.241 & 0.162 \\
Erucic acid (C22:1n9) & 0.030 & 0.020 & 0.039 & 0.024 & 0.034 & 0.020 \\
Total fatty acids & 41.601 & 28.198 & 46.104 & 30.528 & 50.085 & 30.129 \\
\hline BR1 & & & & & &
\end{tabular}

BR1 - diet for pre-fattening, BR2 - diet for fattening, BR3 - diet for post-fattening

15,32 and 38 day of fattening were highly significant $(p \leq 0.01)$. Differences in the mean weight gain in the period from day 1 to 15 of fattening and from day 1 to 38 of fattening were highly significant $(p \leq 0.01)$, in both males and females. 
Table 4. Mean body weight of chickens in the course of the experiment

\begin{tabular}{llcccccc}
\hline $\begin{array}{l}\text { Age } \\
(\text { day })\end{array}$ & Group & $\begin{array}{c}\text { Total } \\
(\mathrm{g} \pm \mathrm{SD})\end{array}$ & $P$ & $\begin{array}{l}\text { Females } \\
(\mathrm{g}, \pm \mathrm{SD})\end{array}$ & $P$ & $\begin{array}{c}\text { Males } \\
(\mathrm{g}, \pm \mathrm{SD})\end{array}$ & $P$ \\
\hline 1 & Control & $43 \pm 0.003$ & NS & $42 \pm 0.003$ & NS & $43 \pm 0.003$ & NS \\
& Experiment & $42 \pm 0.003$ & & $43 \pm 0.004$ & & $43 \pm 0.003$ & \\
15 & Control & $326 \pm 0.09$ & $\leq 0.01$ & $315 \pm 0.09$ & $\leq 0.01$ & $336 \pm 0.09$ & $\leq 0.01$ \\
& Experiment & $433 \pm 0.07$ & & $440 \pm 0.04$ & & $425 \pm 0.08$ & \\
32 & Control & $1521 \pm 0.33$ & $\leq 0.01$ & $1438 \pm 0.27$ & $\leq 0.01$ & $1604 \pm 0.37$ & $\leq 0.01$ \\
& Experiment & $1735 \pm 0.21$ & & $1642 \pm 0.09$ & & $1828 \pm 0.25$ & \\
38 & Control & $2078 \pm 0.40$ & $\leq 0.01$ & $1929 \pm 0.31$ & $\leq 0.01$ & $2228 \pm 0.42$ & $\leq 0.01$ \\
& Experiment & $2341 \pm 0.28$ & & $2184 \pm 0.12$ & & $2498 \pm 0.30$ & \\
\hline
\end{tabular}

(g) (mean \pm SD), NS - non-significant difference

Feed consumption is one of the basic economic criteria for evaluation of fattening (Table 5). The total consumption of a diet within 38 days of fattening was $3.588 \mathrm{~kg}$ (C) and $4.011 \mathrm{~kg}(\mathrm{G})$ in female chickens, and $3.915 \mathrm{~kg}(\mathrm{C})$ and $4.366 \mathrm{~kg}(\mathrm{G})$ in male chickens. The body weight of experimental chickens that were fed the diet containing glycerol increased by $423 \mathrm{~g}$ in females and by $451 \mathrm{~g}$ in males compared to control. In the period of fattening ( 38 days), nett production of chickens (after subtracting the weight of one-day-old chickens) was $58.50 \mathrm{~kg}(\mathrm{C})$ and $67.71 \mathrm{~kg}(\mathrm{G})$ in females and $68.57 \mathrm{~kg}$ (C) and $78.57 \mathrm{~kg}(\mathrm{G})$ in males. The consumption of diets in experimental groups was higher, which was also associated with lower feed conversion in experimental groups: $1.84 \mathrm{~kg}(\mathrm{C})$ and $1.81 \mathrm{~kg}(\mathrm{G})$ in females, and $1.73 \mathrm{~kg}(\mathrm{C})$ and $1.72 \mathrm{~kg}(\mathrm{G})$ in males.

Chickens in both groups did not show any clinical symptoms of diseases throughout the experiment, and no mortality was recorded.

Table 5. Feed consumption and conversion in groups of chickens in individual stages of fattening

\begin{tabular}{|c|c|c|c|c|c|c|c|c|}
\hline & \multicolumn{4}{|c|}{ Consumption of diet } & \multicolumn{4}{|c|}{ Conversion of diet } \\
\hline & \multicolumn{4}{|c|}{ Period (days) } & \multicolumn{4}{|c|}{ Period (days) } \\
\hline & $1-15$ & $15-32$ & $32-38$ & $1-38$ & $1-15$ & $15-32$ & $32-38$ & $1-38$ \\
\hline \multicolumn{9}{|l|}{ Females } \\
\hline Control & 13.15 & 65.00 & 29.50 & 107.65 & 1.55 & 1.46 & 1.94 & 1.84 \\
\hline Experiment & 17.20 & 73.30 & 33.85 & 124.35 & 1.35 & 1.40 & 1.95 & 1.81 \\
\hline \multicolumn{9}{|l|}{ Males } \\
\hline Control & 16.40 & 66.20 & 34.85 & 117.45 & 1.57 & 1.68 & 1.80 & 1.73 \\
\hline Experiment & 20.95 & 76.05 & 38.35 & 135.35 & 1.54 & 1.69 & 1.79 & 1.72 \\
\hline
\end{tabular}

\section{Discussion}

Studies conducted so far have focussed on the use of glycerol in diets to substitute cereals (Peisker and Dersjant-Li 2006) or maize (Simon et al. 1997). The partial substitution of soybean oil with glycerol is a novel approach of addressing the problem of the energy balance in diets, and it was verified in this study.

The replacement of soybean oil with glycerol resulted in qualitative changes in the composition of diets. Such changes were manifested by increased contents of NNES and $\mathrm{NaCl}$, and decreased contents of total protein, crude fat and starch in experimental diets. 
The addition of glycerol had no major effect on the content of individual amino acids and their spectrum. What was considered a beneficial effect from a dietetic point of view was a lowered content of erucic acid. However, the reduction in the contents of essential FAs poses a certain risk. Diets containing $15-20 \%$ of maize and soybean oil are sufficiently supplemented with essential FAs even if soybean oil is replaced with glycerol. This statement is also documented by the results of analysis of diets used in our experiment in which the normalized content of linoleic acid was $19.615 \mathrm{~g}^{\mathrm{kg}} \mathrm{kg}^{-1}$ (BR 1), $21.291 \mathrm{~g} \cdot \mathrm{kg}^{-1}$ (BR 2) and $23.265 \mathrm{~g} \cdot \mathrm{kg}^{-1}$ (BR 3), which exceeds the recommended dose (12.0-12.5 $\mathrm{g} \cdot \mathrm{kg}^{-1}$ of diet) for broiler chickens during fattening, as reported by Zelenka et al. (2007). From a dietetic point of view, the excessive intake of polyunsaturated fatty acids does not always have a positive effect on chickens' health and is not always beneficial in terms of technological properties of produced meat. The combination of soybean oil and glycerol can be considered a suitable solution.

The replacement of soybean oil with glycerol increased the production efficiency of used diets, which was manifested by an increase in chickens' growth intensity and bodyweight at the end of the experiment on 38 day of age: by $13.22 \%$ in females and by $12.12 \%$ in males. Simon et al. (1996) or Barteczko and Kaminski (1999) reported a positive effect of glycerol added up to $5 \%$ (at a maximum addition up to $10 \%$ ) into a diet on the performance indicators of broiler chickens. Thacker et al. (1994) did not confirm a positive effect on the performance indicators of chickens with the use of glycerol in a diet. A number of other authors have reported that the content of glycerol exceeding $10 \%$ in a diet have a negative effect on the performance indicators in fattened chickens. Although the consumption of diets was higher in experimental groups, feed conversion in experimental groups was better, $1.84 \mathrm{~kg}(\mathrm{C})$ and $1.81 \mathrm{~kg}(\mathrm{G})$ in females and $1.73 \mathrm{~kg}(\mathrm{C})$ and $1.72 \mathrm{~kg}(\mathrm{G})$ in males.

There are only few studies regarding the use of glycerol in the nutrition of farm animals. In some species and categories such studies have not yet been conducted. It can be assumed that with the development of rapeseed processing and the increasing production of biodiesel offering large amounts of glycerol as a "waste product", glycerol will become a suitable energy component to be added in feeds for farm animals. One positive finding is the fact that glycerol also improves technological and hygienic quality of granules, as pointed out by Schröder and Südekum (1999). However, a dose of glycerol exceeding $100 \mathrm{~g} \cdot \mathrm{kg}^{-1}$ of feed may pose some technological problems during granulation.

From a standardization point of view, some problems may arise due to the fact that the composition of crude glycerol generated in the production of methylester varies with the technology of oil processing. Different quality affected by the presence of various impurities can therefore be found in literature sources. Major "impurities" include water, methanol, phosphorus and its compounds, sodium chloride and potassium chloride.

The economic evaluation of the use of glycerol is rather problematic due to varying prices of individual feed components. We assume that the replacement of cereals by glycerol is not suitable since the price of cereals is usually lower than the price of glycerol. However, the situation is different when soybean oil is replaced by glycerol because the price of glycerol is several times lower than the price of soybean oil. The price of glycerol is likely to decrease with the overproduction of glycerol generated in the production of methylester. The use of glycerol in diets will therefore become very interesting from an economic point of view.

It follows from our results and literature data that the optimum amount of glycerol in feed for poultry is $5 \%$. If the diet programme is designed properly, it is possible to use $10 \%$ of glycerol in a diet without a negative effect on the performance indicators of animals. However, there are still many issues associated with the use of glycerol in the nutrition of animals that have to be addressed in future research studies. 


\section{Glycerol jako energetický zdroj při výkrmu brojlerových kuřat}

Cílem práce bylo ověřit možnost náhrady sojového oleje glycerolem v dietě brojlerů a sledovat vliv na užitkovost a zdravotní stav brojlerových kuřat. Do pokusu bylo zařazeno 122 jednodenních kuřat, která byla rozdělena podle pohlaví na dvě kontrolní (30 samic a 31 samců) a dvě pokusné (30 samic a 31 samců) skupiny. U krmných směsí určených pro experimentální skupiny kuřat byla provedena $50 \%$ náhrada sojového oleje glycerolem v poměru 1:2. P Kuřata obou pohlaví experimentálních skupin, kterým byly podávány krmné směsi s glycerolem, dosáhla 15., 32. a 38. den výkrmu, statisticky vysoce významně $(p \leq 0.01)$ vyšší průměrnou živou hmotnost ve srovnání s kontrolními skupinami. Na konci pokusu měla kư̌ata kontrolních skupin průměrnou hmotnost $2.078 \mathrm{~kg}$ a kuřata experimentálních skupin $2.341 \mathrm{~kg}$. Celková spotřeba krmné směsi za 38 dnů výkrmu byla u samic z kontrolní skupiny $3.588 \mathrm{~kg}$ a $4.011 \mathrm{~kg}$ u samic z experimentální skupiny, u kohoutků z kontrolní skupiny $3.915 \mathrm{~kg}$ a u kohoutků z experimentální skupiny $4.366 \mathrm{~kg}$, tedy vyšší u pokusných kuřat. Konverze krmiva byla u kuřat pokusných skupin lepší, u samic z kontrolní skupiny $1.84 \mathrm{~kg}$ a u samic z experimentální skupiny $1.81 \mathrm{~kg}$ a u samců z kontrolní skupiny $1.73 \mathrm{~kg}$ a u samců z experimentální skupiny $1.72 \mathrm{~kg}(\mathrm{G} 2)$. Na základě našich výsledků lze za optimální množství glycerolu v krmivech pro drůbež považovat $5 \%$. Práce představuje originální řešení optimalizace krmných směsí náhradou rostlinného oleje glycerolem. Výsledky práce přináší významný produkční i ekonomický dopad ve výkrmu brojlerových kuřat.

\section{Acknowledgements}

Financial support from the Ministry of Education, Youth, and Sports of the Czech Republic (Grant No MSMT $6215712402)$ is gratefully acknowledged.

\section{References}

Anonymous 2003: Regulation No. 318/2003 of 12 September 2003 amending Regulation No. 54/2002 Coll. that specifies safety requirements concerning the identity and purity of additives. E 422 Glycerol. p. 5258

Barteczko J, Kaminski J 1999: The effect of glycerol and vegetable fat on some physiological indices of the blood and excess of fat in broiler carcasses. Ann Warsaw Agricult Univ Anim Sci 36: 197-209

Carew LB, Foss DC 1974: Glycerol in diet of chicks. Poult Sci 53: 1907-1907

Cerrate S, Yan F, Wang Z, Coto C, Sacakli P, Waldroup PW 2006: Evaluation of glycerine from biodiesel production as a geed ingredient for broilers. Int J Poult Sci 5: 1001-1007

Demarne Y, Perazacastro CE, Henry Y, Flanzy J 1977: Effects on lipid fatty-acid composition in different adipose deposits of pig ingesting glycerol tri-dodecanoate (Tri C12=0). Ann Biol Anim Biochim Biophys 17: 137-146

Dozier WA, Kerr BJ, Corzo A, Kidd MT, Weber TE, Bregendal K 2008: Apparent metabolizable energy of glycerin for broiler chickens. Poult Sci 87: 153-153. Suppl. 1

Emmanuel B, Berzins R, Robblee AR 1983: Rates of entry of alanine and glycerol and their contribution to glucose synthesis in fasted chickens. Br Poult Sci 24: 565-571

Hara R, Radin NS 1978: Lipid extraction of tissues with a low-toxicity solvent. Anal Biochem 90: 420-426

Lin MH, Romsos DR, Leveille GA 1976: Effect of glycerol on lipogenic enzyme-activities and on fatty-acid synthesis in rat and chicken. J Nutr 106: 1668-1677

Neville WJ, MacPherson JW, King GJ 1970: The contraceptive action of glycerol in gilts. J Anim Sci 31: 227

Neville WJ, MacPherson, JW, Reinhart B 1971: The contraceptive action of glycerol in chickens. Poult Sci 50: 1411-1415

Peisker M, Dersjant-Li Y 2006: Glycerol in animal nutrition: versatile co-product of biodiesel production. Kraftfutter 89: 16-23

Renner R, Elcombe A 1964: Factors affecting utilization of carbohydrate free diets by nutrition. 2. level of hlycerol. J Nutr 84: 327-330

Schröder A, Karl-Heinz Südekum KH 1999: Glycerol as a by-product of biodiesel production in diets for ruminants. Proceedings of the $10^{\text {th }}$ International Rapeseed Congress, Canberra, Australia. Available at: http://www.regional.org.au/au/gcire/1/241.htm?print=1

Simon A, Bergner H, Schwabe M 1996: Glycerol-feed ingredient for broiler chickens. Arch Anim Nutr 49: 103-112

Simon A, Schwabe M, Bergner H 1997: Glycerol supplementation to broiler rations with low crude protein content. Arch Anim Nutr 50: 271-282 
Thacker PA, Campbell GL, Xu Y 1994: Composition and nutritive-value of acidulated fatty-acids, degummed canola oils and tallow as energy-sources for starting broiler chicks. Anim Feed Sci Technol 46: 251-260

Westfall FD, Howarth B 1976: Effect of time of glycerol deposition on fertility of chickens. Poult Sci 55: 2105-2106

Zelenka J, Heger J, Zeman L 2007: Doporučený obsah živin v krmných směsích a výživná hodnota krmiv pro drůbež (Recommended nutrient content in poultry diets and nutritive value of feeds for poultry). Mendel University in Brno, Brno, 78 p. 